\title{
Är dagens historievetenskap och humaniora fri och kritisk?
}

\author{
Av Jonny Nilsson, doktorand i historia
}

\author{
Länk till presentation av Jonny Nilsson
}

\begin{abstract}
Kritiken mot den historieskrivning som kännetecknade den nationalistiska eran kring förra sekelskiftet, riskerar att bara bli ett patetiskt uttryck för åsikten att dagens historievetenskap är mer fri och höjd över alla lojaliteter. Det sitter i ryggmärgen att betrakta historievetenskapens utveckling under 1900-talet som ett ständigt framåtskridande. Vid seklets början var den en del av ett nationalistiskt samhällsfostrande system. Under 1900talets gång utvecklades den källkritiska metoden, samtidigt som ämnet behöll vissa fostrande funktioner. I samtiden tas det mer eller mindre för givet att historievetenskapen har blommat ut i en praktfull pluralism med ett flertal perspektiv och infallsvinklar, fri från nationalistiska bojor och i stället kritisk i det att den avslöjar maktens förtryckarmekanismer. Historia antas av några rent av ha emancipatoriska kvaliteter.
\end{abstract}

Även om inte alla håller med mig i denna något förenklade beskrivning av utvecklingen så har jag mött den tillräckligt ofta för att påstå att den är framträdande och påträngande. Stämmer den? Den stämmer om man menar att den marxistiska/socialistiska, nyliberala eller genusinriktade historien är en mer upplyst historieskrivning och mer fri från de centrala makthavarna och trend- och överideologier än tidigare epokers. Det kan starkt ifrågasättas.

Min bestämda uppfattning är att den historieskrivning som idag lönar sig genom att den uppmuntras av lärare vid val av uppsatsämne och perspektiv, ger fördelar när man söker forskningspengar, forskarutbildning och tjänster - den är också präglad av de perspektiv och värderingar som genomsyrar riksdag, regering och myndigheter. Det tydligaste exemplet gäller just "genus" och frågor kring jämställdhet som idag har status som en av de viktigaste frågorna i Sveriges beslutande organ. Det är på många sätt den nya tidens religion och alla medborgare skall fostras in i ett jämställt genustänkande på samma sätt som man tidigare skulle fostras till en god fosterlandsälskare, eller som när man på 1960och 1970-talen (och till viss del fortfarande) förväntades betrakta varje detalj av verkligheten utifrån ett klassperspektiv. Hur tydligt slår inte detta igenom i skolorna! Överallt efterlyser man genusperspektiv, och studenter mer eller mindre pressas att använda sig av den infallsvinkeln vid lösning av historiska problem.[1] Vid ansökningar av olika slag förefaller det som att man premierar forskare som anlägger genusperspektiv. Varje skola som vill vara politiskt korrekt har ett genusseminarium. Vissa vill t.o.m. göra genus till ett obligatoriskt ämne i skolan, etc. Denna problematik förefaller prägla hela humaniora och inte bara historieämnet.

Lägg märke till att jag inte kritiserar det lovvärda i att skriva försummade gruppers historia. Det är utmärkt att forskare lyfter fram arbetares, kvinnors, barns, kriminellas och sexualperiferas historia. Kritiken inriktar sig på den till synes självklara favorisering av specifika perspektiv som idag sker, samt den bristande medvetenheten vad gäller bundenheten till maktens centra. Det skall också sägas att en del av mina uppfattningar ännu bara är hypoteser och att noggranna undersökningar borde göras om vad som premieras vid tjänstetillsättningar, forskningsansökningar, samt vad lärarna uppmuntrar för perspektiv vid uppsatsskrivning. Annars finns risken att mina åsiktsmotståndare avfärdar mina hypoteser som gissningar utan verklighetsgrund. Man borde också undersöka sambandet mellan historievetenskapen och de beslutande organen. Någon kanske vill 
hävda en antites, nämligen att det är universitetens fokusering på jämställdhet och genus som smittat av sig på makthavarna.

Jag menar dock att man inte behöver ha någon större analytisk förmåga för att inse att dagens historievetenskap och humaniora inte alls är speciellt fri och kritisk. Det räcker inte med att säga att de nya trenderna är ett resultat av att de tidigare har blivit försummade. Vi har också bytt överideologi. Nya forskargenerationer inskolas i de värderingar som gäller idag. Skolornas kritiska dimension består huvudsakligen i att man får ifrågasätta det förgångna, men den som ifrågasätter dagens grunder riskerar snabbt att gå miste om både sin forskarheder och de pengar som gör att han kan fortsätta producera historiska berättelser.

Jag vill alltså plädera för att dagens historieämne eller humaniora som helhet behöver bli mer kritiska gentemot dagens rådande värderingar genom en ökad reflexion. Det kan tyckas självklart, men i vardagspraktiken är det "det självklaras" tyranni som råder.

\section{(C) Jonny Nilsson}

[1] Vid ett samtal med en student på annan ort än Växjö framkom att hon av handledaren hade fått uppmaningen att anlägga ett genusperspektiv. På så sätt skulle hon slippa mycket kritik under seminariet och öka sina chanser för att få betyget väl godkänd. 